\title{
Penggunaan antibiotik di dua apotek di Surabaya: identifikasi faktor-faktor yang mempengaruhi kepatuhan pasien
}

\author{
Wahyu Dewi Tamayanti ${ }^{1}$, Windrianita D.M. Sari ${ }^{1}$, Dian Novita Dewi ${ }^{2}$ \\ ${ }^{1}$ Departemen Farmasi Klinis dan Komunitas, Fakultas Farmasi, Universitas Katolik Widya Mandala \\ ${ }^{2}$ Departemen Farmakologi, Fakultas Kedokteran, Universitas Katolik Widya Mandala \\ Jln. Raya Kalisari Selatan 1, Pakuwon City, Surabaya
}

Submitted: 24-05-2016

Reviewed: 04-10-2016

Accepted: 03-11-2016

\begin{abstract}
ABSTRAK
Perhatian terhadap faktor-faktor yang mengarah kepada kepatuhan penggunaan antibiotik perlu dilakukan agar masyarakat terhindar dari resistensi. Penelitian ini bertujuan mengidentifikasi faktorfaktor yang mempengaruhi kepatuhan pasien dalam penggunaan antibiotik di 2 apotek di Kota Surabaya. Subjek penelitian prospektif ini adalah masyarakat yang membeli antibiotik di dua apotek, yaitu Apotek Bhumyamca (A) dan Apotek Tiara 2 (B). Data dikoleksi melalui kuisioner teruji, dianalisa dengan statistik deskriptif, dan diuji regresi berganda Hosmer and Lemeshow's. Faktor usia, jenis, penghasilan, durasi dan pola penggunaan antibiotik, informasi antibiotik, keluhan dan tindakan setelah timbul efek samping antibiotik diamati. Sebanyak 94 responden memenuhi kriteria inklusi umumnya wanita, $74 \%$ di apotek A dan 68\% di apotek B. Penghasilan responden berkisar 2 - 3 juta rupiah 83\% di Apotek A dan 54\% di apotek B. Responden menggunakan antibiotik selama 3-5 hari, 47\% di Apotek A dan 50\% di apotek B. Sebagian besar responden menggunakan antibiotik setelah makan sebanyak $92 \%$ di Apotek A dan $88 \%$ di apotek B. Informasi antibiotik diperoleh responden dari tenaga kesehatan sebesar $92 \%$ di Apotek A dan 85\% di apotek B. Responden tidak memiliki keluhan setelah konsumsi antibiotik dengan hasil $87 \%$ di Apotek A dan 73\% di apotek B. Sebanyak 56\% responden di kedua Apotek menghentikan penggunaan antibiotik saat terjadi keluhan sedangkan $44 \%$ berobat ke dokter. Responden di Apotek A (86\%) dan di apotek B (89\%) menunjukkan kepatuhan terhadap instruksi pemakaian saat mengkonsumsi antibiotik. Penelitian menyimpulkan, tidak ada hubungan antara seluruh faktor yang dianalisa terhadap kepatuhan penggunaan antibiotik, kecuali pola penggunaan antibiotik di apotek B $(0,011)$.
\end{abstract}

Kata kunci: kepatuhan pasien, penggunaan antibiotik, apotek Bhumyamca, Apotek Tiara

\section{ABSTRACT}

Attention to factors that affects proper use of antibiotics need to be conducted to prevent community resistance. This study was aimed to identify factors that affect patients' compliance of antibiotic use in two pharmacies in Surabaya, Bhumyamca (A) and Tiara 2 (B). Subject of this study was people who purchased antibiotics in the two pharmacies. Data were collected through questionnaires, analyzed using descriptive statistic, and underwent Hosmer and Lemeshow's multiple regression tests. Factors such as: age, gender, income, duration and pattern of antibiotics use, antibiotics information, complaint and action after antibiotics side effect were observed. There were 94 respondents mainly 26 31 of age met the inclusion criteria. Female respondents in A were $74 \%$ and $68 \%$ in B. Respondents income was 2 to 3 million rupiah, in A (83\%) and B (54\%). Respondents use antibiotics mainly for 3 to 5 days, in A (47\%) and B (50\%). Most respondents use antibiotics after meals in A (92\%) and B (88\%).

Penulis korespondesi:

Wahyu Dewi Tamayanti

Fakultas Farmasi, Universitas Katolik Widya Mandala

Jln. Raya Kalisari Selatan 1, Pakuwon City, Surabaya

Email: wahyudewi@ukwms.ac.id 
Antibiotics information was obtained mainly from healthcare providers in A (92\%) and B (85\%). Respondents had no complaints after antibiotics use in A (87\%) and B (73\%). Respondents (44\%) stop antibiotics when complaints were occurred both in $\mathrm{A}$ and $\mathrm{B}$, whereas $56 \%$ visited clinician. Respondents in A (86\%) and B (89\%) were consumed antibiotics in accordance to usage instruction. Conclusively, no factor was associated to patients' compliance, except pattern of administration in B (0.011).

Keywords: patients' compliance, antibiotics usage, pharmacy

\section{PENDAHULUAN}

Antibiotik adalah terapi untuk mengatasi infeksi bakteri (Nelwan, 2006). Antibiotik harus digunakan secara rasional untuk mengoptimalkan fungsinya. Pemakaian antibiotik dikatakan rasional jika, tepat: indikasi, dosis, interval, durasi, dan harga (WHO, 2004). Penggunaan antibiotik yang tidak rasional dapat menyebabkan pemborosan biaya kesehatan, resiko efek samping, perpanjangan waktu perawatan, penurunan atau hilangnya sensitivitas bakteri terhadap antibiotik, dan resiko resistensi bakteri (Qibtiyah, 2005; Azevedo et al., 2009).

Sebuah penelitian yang dilakukan di Kota Surabaya Barat melaporkan beberapa faktor yang mempengaruhi penggunaan antibiotik pada masyarakat yang membeli obat didua apotek di kota tersebut, antara lain: penghasilan, jenis keluhan masyarakat, sumber informasi terkait antibiotik, serta dilayaninya pembelian antibiotik tanpa resep melalui apotek (Krisdianto et al., 2014). Penelitian lain menunjukkan bahwa pembelian antibiotik tanpa resep dilayani di beberapa apotek di wilayah Kota Surabaya. Keadaan ini terbukti setelah dilakukan skenario "simulasi pasien" yang membeli tablet siprofloksasin, kapsul tetrasiklin tanpa resep, dan sirup kering amoksisilin dengan resep baru. Sebanyak 80 apotek dari 105 apotek tujuan penelitian melayani pembelian antibiotik tanpa resep. Antibiotik dapat langsung dibeli oleh pasien tanpa dilengkapi informasi mengenai tablet siprofloksasin dan kapsul tetrasiklin. Informasi hanya diberikan bila pasien bertanya (Puspitasari et al., 2011).

Pelayanan antibiotik yang tidak semestinya oleh tenaga kesehatan dapat menjadi salah satu pemicu eksternal terjadinya ketidakrasionalan penggunaan antibiotik, yang umumnya tanpa disertai informasi kepada pasien setelah membeli antibiotik tanpa resep. Kondisi tersebut mempengaruhi tingkat resistensi antibiotik. Laporan WHO menyatakan bahwa kasus resistensi di Kota Surabaya mencapai 2494 kasus diantaranya terhadap ampicillin (34\%), trimetoprim/sulfametoksazol (29\%), dan kloramfenikol (15\%) (WHO, 2001).

Penggunaan antibiotik secara rasional perlu dilandasi adanya pengetahuan tentang antibiotik yang dapat diberikan oleh tenaga kesehatan baik dokter maupun apoteker kepada pasien tentang efek farmakologis, efek samping, interaksi obat, dan instruksi penggunaan. Informasi tersebut adalah dasar bagi pasien dalam menggunakan antibiotik secara rasional. Selain itu, informasi dari dokter maupun apoteker juga diperlukan untuk mendukung kepatuhan pasien dalam penggunaan antibiotik secara rasional (Akici et al., 2004). Notoatmodjo (2007) menyampaikan bahwa pengetahuan merupakan salah satu faktor yang berperan dalam menginterpresentasikan stimulus yang diperoleh. Oleh karena itu adanya pengetahuan tentang antibiotik yang memadai dapat berdampak pada kepatuhan penggunaan antibiotik. Penelitian ini dilakukan dengan tujuan untuk mengidentifikasi faktor-faktor yang mempengaruhi kepatuhan pasien dalam penggunaan antibiotik pada masyarakat yang membeli antibiotik di dua Apotek di Kota Surabaya.

\section{METODE PENELITIAN}

\section{Rancangan dan subyek penelitian}

Penelitian cross sectional ini dilakukan dengan menggunakan alat bantu kuesioner tervalidasi untuk pengambilan data. Pengambilan data dilakukan secara time limited mulai Februari sampai Mei 2014 pada 94 pasien rawat jalan yang membeli antibiotik di Apotek Bhumyamca II (A) dan Tiara 2 (B) Surabaya. Kedua apotek tersebut melayani setidaknya 30 resep dengan antibiotik tiap bulan sehingga dipilih mewakili area Surabaya Timur dan Barat. Pasien direkrut secara purposive sampling dengan memenuhi kriteria berikut: berusia 20 - 55 tahun, bisa membaca dan menulis, dan membeli antibiotik dengan resep. 


\section{Tahapan penelitian}

Pengujian kuisioner

Sebelum menggunakan kuisioner, dilakukan uji coba kuisioner pada 10 pengguna antibiotik dan 10 orang yang belum pernah menggunakan antibiotik. Pada uji coba ini, digali pemahaman responden terhadap kalimat dalam kuisioner. Kalimat yang tidak dipahami responden direvisi sehingga lebih mudah dipahami.

\section{Pengambilan data}

Pengambilan data dilakukan dengan pengisian kuisioner oleh responden setelah mengisi informed consent dengan didampingi oleh peneliti. Peneliti memberikan informasi yang diperlukan sesuai pertanyaan responden tanpa mengarahkan responden ke jawaban. Proses pengisian kuisioner direkam untuk mengetahui kemungkinan bias jawaban peneliti dalam menjawab pertanyaan responden.

\section{Tabulasi, skoring, dan analisa data}

Pada penelitian ini, variabel bebas adalah usia, jenis kelamin, penghasilan, pengetahuan akan pengertian antibiotik, sumber informasi antibiotik, jenis informasi antibiotik, frekuensi penggunaan antibiotik, pola penggunaan antibiotik, keluhan dan tindakan setelah mengalami efek samping antibiotik. Variabel tergantung adalah kepatuhan pasien. Data yang diperoleh dikelompokkan dan ditabulasi. Pada data yang telah ditabulasi kemudian dilakukan skoring untuk memenuhi syarat dilakukan analisis regresi berganda khusus dengan Hosmer and Lemeshow's test, menggunakan bantuan software SPSS versi 21.

\section{HASIL PENELITIAN \\ Deskripsi hasil penelitian}

Pada bagian ini akan dideskripsikan secara singkat hasil penelitian pada tabel 1 yang kemudian akan diikuti dengan diskusi hasil. Pada Tabel I terdapat 94 responden yang berpartisipasi dalam penelitian ini, 57 responden dari Apotek A dan 37 responden dari Apotek B. Pada tabel tersebut terdata responden perempuan menunjukkan persentase lebih tinggi pada kedua apotek dibanding responden lelaki (74\% pada apotek A dan 68\% pada apotek B). Pada data usia, kisaran usia 26-31 tahun adalah yang tertinggi dibandingkan kisaran usia responden yang lain, yaitu mencapai $70 \%$ pada kedua apotek. Responden pada apotek A memiliki penghasilan mayoritas di atas 5 juta $(83 \%)$ dibandingkan penghasilan responden di Apotek B yang bervariasi dengan persentase tertinggi antara antara 2-3 juta (54\%). Pengetahuan responden tentang antibiotik dalam penelitian ini terlihat dari jawaban mereka atas pertanyaan durasi penggunaan antibiotik, yaitu 47\% (apotek A) dan 50\% (apotek B) responden menggunakan antibiotik selama 3-5 hari. Pengetahuan responden juga diukur dari jawaban mereka atas pertanyaan pola penggunaan antibiotik, yaitu sesudah makan (92\% pada apotek A dan $88 \%$ pada apotek B). Menurut responden ( $92 \%$ di apotek A dan $85 \%$ di apotek B), pengetahuan antibiotik mereka peroleh dari tenaga kesehatan yaitu dokter, perawat, dan apoteker. Seputar keluhan setelah konsumsi antibiotik, responden di kedua apotek mayoritas tidak mengalami keluhan, yaitu 86\% di Apotek A dan 73\% di Apotek B. Pada responden, ditanyakan pula mengenai tindakan yang dilakukan semisal mendapati terjadinya keluhan. Mayoritas responden menjawab menemui dokter (56\% di Apotek A dan B) dan menghentikan konsumsi antibiotik (44\% di Apotek A dan B). Ketika responden diminta menjawab pertanyaan: “Apakah Anda patuh terhadap instruksi saat menggunakan antibiotik?". Sebagian besar responden menjawab "ya" (86\% pada Apotek A, dan 89\% pada Apotek B).

Faktor-faktor yang diujikan kepada responden melalui kuisioner kemudian diolah dan dianalisa regresi berganda. Faktor yang dianalisa adalah jenis kelamin, usia, penghasilan, durasi, pola penggunaan, sumber informasi, keluhan efek samping, dan tindakan saat timbul efek samping. Analisis menggunakan uji regresi berganda dilakukan khususnya untuk menguji korelasi antara faktor yang diuji dengan kepatuhan responden. Kelayakan model regresi dinilai dengan Hosmer and Lemeshow's Goodness of fit test. Hasil analisa menunjukkan nilai probabilitas sebesar 0,754 yang berarti model regresi logistik yang digunakan layak dipakai untuk analisis selanjutnya sebab tidak ditemukan perbedaan nyata antara klasifikasi yang diprediksi dengan yang diamati (Sujarweni, 2014). Uji regresi berganda juga mensyaratkan penilaian fitness of the model. Model regresi dikatakan fit dengan data jika terdapat penurunan nilai -2LL awal dengan nilai -2LL pada langkah berikutnya (Sujarweni, 2014). Dalam penelitian ini, nilai -2LL awal adalah 71,80 dan nilai -2LL berikutnya adalah 46,79 sehingga model regresi linier yang dihipotesakan fit dengan data. Uji regresi linier yang telah melewati kedua syarat 
tersebut dapat digunakan untuk analisis selanjutnya. Pada Tabel I ditampilkan hasil uji regresi berganda khusus, yang hasilnya melaporkan tidak adanya hubungan antara poin-poin dalam pertanyaan terhadap kepatuhan responden (nilai sig. > 0,05), kecuali pola pemberian antibiotik di Apotek B $(0,011)$ (Tabel I, Gambar 1).
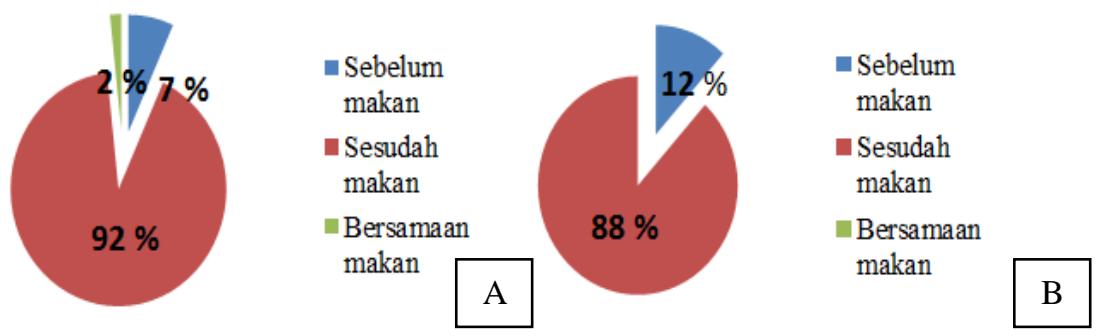

Gambar 1. Distribusi pola pemberian antibiotik di Apotek Bhumyamca II (A) dan Tiara 2 (B)

\section{Pembahasan hasil penelitian}

Pada bagian ini akan dibahas hasil pada penelitian ini untuk menjawab tujuan penelitian sehingga dapat ditarik sebuah kesimpulan. Faktor awal yang dianalisa adalah termasuk dalam faktor demografi yaitu jenis kelamin. Jenis kelamin perempuan adalah responden mayoritas penelitian ini, dan hasil analisa statistik menunjukkan bahwa jenis kelamin lelaki ataupun perempuan tidak mempengaruhi kepatuhan dalam menggunakan antibiotik. Hal ini dapat terjadi karena pada era ini, baik lelaki ataupun perempuan memiliki kebebasan dalam mengakses informasi yang mereka butuhkan. Jenis kelamin tidak membatasi rasa ingin tahu dalam mengakses informasi. Akses informasi dapat mempengaruhi keyakinan (belief) responden dalam mengkonsumsi antibiotik sebab keyakinan merupakan salah satu faktor pendukung timbulnya hambatan perilaku unintentional adherence (Morgan \&Horne, 2005 pada responden lelaki maupun perempuan.

Aspek demografi lain yaitu usia, hasil analisa regresi berganda menunjukkan tidak ada hubungan antara usia dengan kepatuhan responden dalam mengkonsumsi antibiotik. Sekalipun tidak terdapat korelasi antara usia dan kepatuhan dalam mengkonsumsi antibiotik, namun pada penelitian ini, responden yang mayoritas berusia 26-31 tahun dan tergolong dalam usia produktif menurut Depkes RI (2009) mampu menjawab benar pertanyaan durasi dan pola penggunaan antibiotik. Responden pun mengetahui dengan benar tindakan yang harus diambil apabila timbul keluhan efek samping setelah menggunakan antibiotik, yaitu menghentikan minum antibiotik dan menemui dokter. Hasil tersebut mengindikasikan bahwa responden kisaran usia produktif memiliki pengetahuan terkait konsumsi antibiotik yang sedang dilakukannya saat penelitian berlangsung. Kondisi ini menjadi menarik karena usia ternyata secara statistik tidak berpengaruh terhadap kepatuhan dalam mengkonsumsi antibiotik. Mengapa hal ini dapat terjadi? Sebuah teori menjelaskan bahwa kepatuhan responden dalam mengkonsumsi obat dipengaruhi oleh beberapa faktor. Sebelumnya, perlu disepakati bahwa kepatuhan (compliance) yang dalam penelitian ini mengacu ke istilah adherence, merupakan perilaku untuk mentaati saran-saran atau prosedur dari dokter tentang penggunaan obat, yang sebelumnya didahului oleh konsultasi antara pasien (dan atau keluarga inti pasien dengan dokter (Osterberg dan Blaschke, 2005). Teori tersebut mengindikasikan bahwa kepatuhan berkaitan erat dengan perilaku. Perilaku patuh dalam mengkonsumsi obat merupakan proses yang diawali oleh Health Belief, yaitu keyakinan personal akan ancaman penyakit serta keuntungan dari saran yang diberikan oleh tenaga kesehatan (Morgan dan Horne, 2005 dalam Lailatusifah, 2009). Ketika seseorang meyakini bahwa penyakitnya serius, diduga akan lebih patuh dalam mengkonsumsi obat sebab mereka yakin bahwa obat akan membantu meredakan penyakit. Pada penelitian ini, diduga responden usia produktif meyakini bahwa penyakit mereka bukanlah sesuatu yang serius sehingga mempengaruhi kepatuhan dalam mengkonsumsi antibiotik. Oleh karena keyakinan yang bias akan keseriusan penyakitnya, responden pada usia tersebut diduga kurang mampu mengontrol perilaku dalam mengendalikan kepatuhan dalam konsumsi antibiotik (Morgan dan Horne, 2005). Sebagai tambahan, responden pada usia tersebut bisa jadi memiliki hambatan berupa unintentional adherence, yaitu kurang pengetahuan spesifik akan pentingnya minum antibiotik secara teratur, dan responden 
mungkin memiliki kesulitan dalam melakukan rutinitas normal harian (Morgan dan Horne, 2005). Unintentional adherence sangat mungkin terjadi pada responden usia produktif yang memiliki banyak aktivitas di luar proses pengobatan yang sedang dijalaninya.

Pada aspek demografi tentang penghasilan, hasil analisa regresi menunjukkan tidak adanya hubungan antara kepatuhan mengkonsumsi antibiotik terhadap besar penghasilan responden, yang mayoritas berpenghasilan diatas 5 juta di Apotek A dan 2-3 juta di Apotek B. Tinggi atau rendahnya penghasilan terbukti tidak mempengaruhi kepatuhan responden dalam pemakaian antibiotik salah satunya karena semakin meratanya dukungan pemerintah bagi seluruh kalangan masyarakat untuk memperoleh fasilitas obat di negara kita. Khususnya masyarakat menengah ke bawah dapat memperoleh obat dengan harga yang terjangkau dengan mutu serta keamanan yang terjamin yang dicetuskan dalam Peraturan Menteri Kesehatan RI No. 189/Menkes/SK/III/2006 yang "menjamin ketersediaan, pemerataan dan keterjangkauan obat terutama obat esensial dengan ruang lingkup yang mencakup pembiayaan, ketersediaan serta pemerataan obat bagi masyarakat" - menguntungkan bagi masyarakat menengah ke bawah dalam mensejahterakan tingkat kesehatan mereka. Keadaan ini diduga dapat menjelaskan mengapa penghasilan responden tidak berhubungan dengan kepatuhan mengkonsumsi antibiotik. Pada kalangan manapun, tidak ada alasan tidak patuh mengkonsumsi karena tidak mampu membeli antibiotik.

Penelitian ini juga mengukur pengetahuan responden tentang antibiotik dan mengkorelasinya dengan kepatuhan dalam menggunakan antibiotika. Penelitian ini mengukur pengetahuan melalui pertanyaan berikut, yaitu: durasi penggunaan antibiotik, pola penggunaan antibiotik, dan tindakan yang dilakukan saat timbul keluhan. Jawaban benar responden akan pertanyaan-pertanyaan tersebut mengindikasikan bahwa responden memiliki pengetahuan akan antibiotik, yang menurut mereka (sebagian besar informasi) diperoleh dari tenaga kesehatan. Menariknya, pengetahuan pasien pada usia tersebut tidak terkorelasi linear terhadap kepatuhan dalam mengkonsumsi antibiotik setelah analisa dengan uji regresi berganda. Hasil penelitian berikut mendukung hasil penelitian ini. Penelitian terdahulu telah dilakukan di Yogjakarta melaporkan terdapatnya kesalahan persepsi responden dalam memahami antibiotik. Persepsi responden sebagai berikut: "antibiotik harus digunakan segera ketika terjadi demam" atau "antibiotik dapat mengatasi infeksi virus" (Widayati et al., 2012). Sebuah teori mengatakan bahwa pengetahuan tidak cukup untuk mengubah perilaku, namun membentuk kepercayaan dan attitude (tindakan). Konsekuensinya adalah, pengetahuan yang salah akan antibiotik dapat menyebabkan timbulnya kesalahan persepsi yang berujung ke kesalahan tindakan (Conner dan Norman, 2005). Responden pada penelitian ini mungkin memiliki persepsi awal yang salah akan penggunaan antibiotik seperti dideskripsikan di atas sehingga mempengaruhi kepatuhan dalam mengkonsumsi antibiotik.

Responden dalam penelitian ini mengaku patuh dalam mengkonsumsi antibiotik dan terbukti dari tidak ada keluhan saat mengkonsumsi antibiotik, sekalipun secara statistik, faktor keluhan tidak berkorelasi linear terhadap kepatuhan responden dalam konsumsi antibiotik. Hal ini dapat terjadi karena responden pada penelitian ini menggunakan antibiotik dalam durasi singkat, sehingga mereka terhindar dari efek samping.

Faktor-faktor yang dieksplorasi dalam penelitian ini, baik faktor demografi maupun faktor pengetahuan, secara statistik tidak terbukti mempengaruhi kepatuhan pasien dalam konsumsi antibiotik. Horne (2006) secara umum menyampaikan empat faktor yang mempengaruhi pasien dalam mengkonsumsi obat, yaitu: persepsi dan perilaku pasien, komunikasi medis antara pasien dan dokter, kebijakan dan praktek pengobatan publik yang dicetuskan oleh pihak berwenang (seperti: sistem pajak dalam resep, dan hak-hak konsumen dalam pembuatan resep), intervensi yang diterapkan di rumah sakit saat perawat melakukan kunjungan bangsal, dan peningkatan pemahaman pasien akan obat yang diberikan oleh apoteker di apotek. Ulasan hasil penelitian ini mengindikasikan bahwa pengetahuan pasien akan obat yang dikonsumsi tidak berpengaruh terhadap kepatuhan dalam mengkonsumsi obat. Namun mengacu pada teori Horne (2006), pemberian informasi obat merupakan salah satu faktor yang dapat mempengaruhi kepatuhan pasien, oleh sebab itu pemberian informasi obat harus terus dilakukan secara kontinu oleh apoteker kepada pasien yang membeli obat di apotek. 
Tabel. I Hasil uji deskriptif dan uji regresi berganda

\begin{tabular}{|c|c|c|c|c|}
\hline Variabel & $\begin{array}{l}\text { Persentase } \\
(\mathrm{n}=57) \\
\text { Bhumyamca II }\end{array}$ & $\begin{array}{c}\begin{array}{c}\text { Persentase } \\
(\mathrm{n}=\mathbf{3 7})\end{array} \\
\text { Tiara } 2\end{array}$ & \multicolumn{2}{|c|}{ Analisis regresi berganda } \\
\hline \multicolumn{5}{|l|}{ Jenis kelamin } \\
\hline - Laki-laki & 26 & 32 & 0,927 & 0,088 \\
\hline - Perempuan & 74 & 68 & & \\
\hline \multicolumn{5}{|l|}{ Usia } \\
\hline - 26-31 tahun & 70 & 70 & 0,431 & 0,391 \\
\hline - $32-37$ tahun & 18 & 27 & & \\
\hline - $38-43$ tahun & 7 & - & & \\
\hline - 44-49 tahun & 5 & 3 & & \\
\hline \multicolumn{5}{|l|}{ Penghasilan } \\
\hline$-\quad<1$ juta & 17 & 11 & 0,873 & 0,256 \\
\hline - 2-3 juta & - & 54 & & \\
\hline - $3-5$ juta & - & 27 & & \\
\hline$->5$ juta & 83 & 8 & & \\
\hline \multicolumn{5}{|l|}{ Durasi } \\
\hline - $<3$ hari & 34 & 33 & 0,192 & 0,071 \\
\hline - 3-5 hari & 47 & 50 & & \\
\hline$->5$ hari & 7 & 6 & & \\
\hline - Tidak tahu & 12 & 11 & & \\
\hline \multicolumn{5}{|l|}{ Pola penggunaan } \\
\hline - Sebelum makan & 7 & 12 & 0,125 & $0,011 *$ \\
\hline - Sesudah makan & 92 & 88 & & \\
\hline - Bersama makan & 2 & - & & \\
\hline \multicolumn{5}{|l|}{ Sumber informasi } \\
\hline $\begin{array}{ll}\text { - } & \text { Tenaga } \\
\text { kesehatan }\end{array}$ & 92 & 85 & 0,867 & 0,179 \\
\hline - Etiket & 3 & 9 & & \\
\hline - Teman/keluarga & 5 & 6 & & \\
\hline \multicolumn{5}{|l|}{ Keluhan } \\
\hline - Diare & 7 & 5 & 0,742 & 0,999 \\
\hline - Mual & 7 & 6 & & \\
\hline - Demam & - & 16 & & \\
\hline - Tidak terjadi & 86 & 73 & & \\
\hline \multicolumn{5}{|l|}{ Tindakan } \\
\hline - Stop antibiotik & 44 & 44 & 0,478 & 0,998 \\
\hline - Ke dokter & 56 & 56 & & \\
\hline - Ke apotek & - & - & & \\
\hline \multicolumn{5}{|l|}{ Kepatuhan } \\
\hline - Ya & 86 & 89 & & \\
\hline - Tidak & 1 & 11 & & \\
\hline
\end{tabular}

*bermakna secara statistik $(\mathrm{p}<0,05)$

\section{KESIMPULAN}

Faktor demografi (usia, jenis kelamin dan penghasilan) serta pengetahuan akan antibiotik (fungsi, durasi pemakaian, pola penggunaan, efek samping, aturan pakai dan tindakan yang diambil saat timbul efek samping) tidak berhubungan dengan kepatuhan pasien dalam mengkonsumsi antibiotik. 


\section{DAFTAR PUSTAKA}

Akici, A., Kalaca, S., Ugurlu, M.U., Toklu, H.Z., Iskender, E., and Oktay, Sule., 2004, Patient knowledge about drugs prescribed at primary healthcare facilities. Pharmacoepidemiology and Drug Safety, 13: 871-876

Azevedo, M.M., Pinheiro, C., Yaphe, J., and Baltazar, F., 2009, Portuguese students' knowledge of antibiotics: a cross-sectional study of secondary school and university students in braga. BioMed Central, p. 1-6.

Conner M, Norman P (Eds). 2005, Predicting Health Behaviour: Research and Practice with Social Cognition Models. 2nd edition. England: Open University Press.

Departemen Kesehatan Republik Indonesia. 2009, Profil Kesehatan Indonesia 2008. Jakarta, Departemen Kesehatan RI, p. 3-6.

Horne, R. 2006, Compliance, adherence dan concordance: implications for asthma treatment. CHEST, Official Publications of American College of Chest Physicians, 130: 65-72.

Krisdianto B.D.N., Tamayanti W.D., Soegiarto EV. Oktober 2014, Eksplorasi faktor yang mempengaruhi penggunaan antibiotik di apotek k24 wiyung dan karah agung surabaya. Jurnal Widya Medika, 2 (2), 82-87.

Morgan, M., Horne, R., Explaining patient's Behavior. 2005, Report for the national Co-ordinating Centre for NHS Service Delivery dan Organisation R dan D (NCCSDO). Centre for Health Care Research, University of Brighton, Falmer, Brighton.

Nelwan, R.H.H, 2006. Pemakaian Antimikroba Secara Rasional di Klinik, Buku Ajar Ilmu Penyakit Dalam. Jakarta : Pusat Penerbitan Departemen Ilmu Penyakit Dalam FK UI.

Notoatmodjo, S., 2007. Promosi Kesehatan dan Ilmu Perilaku. Jakarta. PT. Rineka Cipta, p. 86.

Osterberg, L., Blaschke, T. 2005, Drug therapy: adherence to medication. The New England Journal of Medicine, 353: 487-497.

Puspitasari HP, Faturrohmah A, Hermansyah A. Do indonesian community pharmacy workers respond to antibiotics requests appropiately? Tropical Medicine and International Health. July 2011, 16 (7) pp 840-846.

Qibtiyah, M., 2005, Kumpulan Makalah Pendidikan Farmasis Berkelanjutan XXV: Penggunaan antibiotika: Dampak penggunaan antibiotika terhadap resistensi. Surabaya: BPD ISFI Jawa Timur, Fakultas Farmasi Universitas Airlangga, Balai Besar POM Surabaya

Sujarweni, V.W. 2014, SPSS untuk penelitian. Pustaka Baru Press. 160 - 176.

Widayati A, Suryawati S, de Crespigny C, Hiller JE., 2012, Knowledge and beliefs about antibiotics among people in yogjakarta city indonesia: a cross sectional population-based survey. Antimicrobial Resistance and Infection Control, (1) 38.

World Health Organization, 2001, WHO Global Strategy for Containtment of Antimicrobial Resistance 2001, Switzerland: World Health Organization.

World Health Organization, 2004, WHO Medicines Strategy Countries At The Core 2004-2007. Geneva: World Health Organization. 
